\title{
Another win for multiarterial bypass grafting: What's next?
}

\author{
Carlos O. Encarnacion, MD, ${ }^{\mathrm{a}}$ and G. Hossein Almassi, $\mathrm{MD}^{\mathrm{b}}$
}

\author{
From the ${ }^{\mathrm{a} D i v i s i o n}$ of Cardiac Surgery, University of Maryland School of Medicine, Baltimore, Md; and ${ }^{\mathrm{b}}$ Division \\ of Cardiothoracic Surgery, Medical College of Wisconsin, Milwaukee, Wis. \\ Disclosures: Authors have nothing to disclose with regard to commercial support. \\ Received for publication Feb 28, 2018; accepted for publication March 5, 2018; available ahead of print March 28, \\ 2018. \\ Address for reprints: G. Hossein Almassi, MD, Division of Cardiothoracic Surgery, Medical College of Wiscon- \\ sin, 8701 Watertown Plank Rd, Milwaukee, WI 53226 (E-mail: halmassi@mcw.edu). \\ J Thorac Cardiovasc Surg 2018;156:52-3 \\ 0022-5223/\$0.00 \\ Published by Elsevier Inc. on behalf of The American Association for Thoracic Surgery \\ https://doi.org/10.1016/j.jtcvs.2018.03.010
}

Multiple arterial coronary grafting continues to be studied both retrospectively and prospectively. In a populationbased observational study of 20,076 patients by $\mathrm{Pu}$ and colleagues, ${ }^{1}$ multiarterial grafting was associated with reductions in mortality, repeated revascularization, myocardial infarction, and heart failure relative to single internal thoracic artery grafting. The advantage of this revascularization strategy has been demonstrated in the nonobese population; however, the optimal revascularization for patients affected by diabetes or obesity remains inconclusive. The report by Schwann and colleagues ${ }^{2}$ in the current issue of the Journal helps to address this gap in the literature.

In line with their group's previous reports on multiple arterial coronary grafting with the use of radial artery as the second-choice arterial conduit, Schwann and colleagues $^{2}$ have added impetus to the choice of multiarterial grafting as the standard in surgical coronary revascularization. Their report focused on a controversial subset of patients requiring coronary revascularization, retrospectively studying 6102 patients with 2536 (41.6\%) who were obese, subdivided into body mass index categories (mild obesity and morbid obesity). This grouping differs from their group's previous publication on the topic ${ }^{3}$ and other reported classifications on obesity. ${ }^{4}$ There were differing characteristics between the left internal thoracic artery with saphenous vein bypass grafting group and the radial artery in multiple arterial coronary grafting group, who were younger, were more likely to be male, and had a higher revascularization index. Of note, no data were reported on where the radial artery was anastomosed. Of interest would be an analysis of arterial graft end targets to investigate whether there were any significant differences in study end points. Their study displayed long-term survival benefit from 0 to 15 years in both obese (hazard ratio, $0.85 ; 95 \%$ confidence interval, 0.74-0.98) and nonobese (hazard ratio, $0.91 ; 95 \%$ confidence interval, 0.80-1.03) patients, although, the survival advantage in obese patients was principally driven by a significantly lower mortality hazard ratio in mildly obese patients in population. investigation.

\section{References}

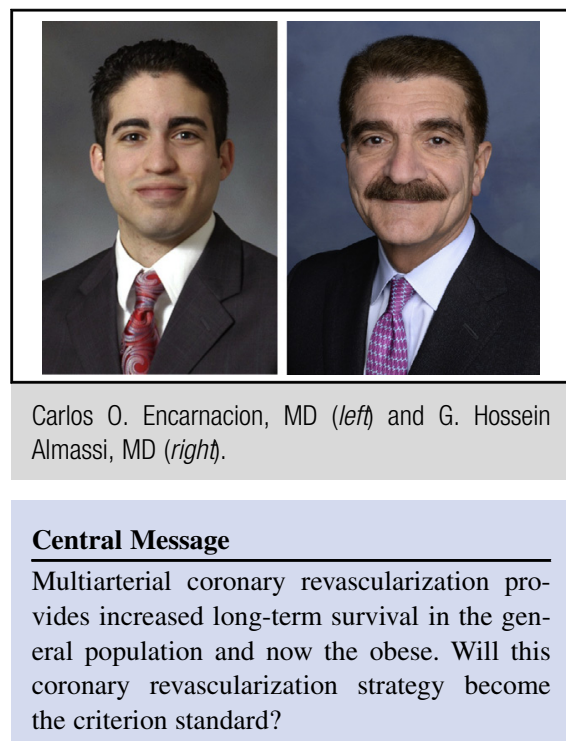

See Article page 43.

the intermediate interval (0.5-5 years). Nonetheless, and to a large extent, this report has addressed the debated optimal revascularization strategy for the obese patient

Bilateral internal thoracic artery use was an exclusion criterion; Schwann and colleagues ${ }^{2}$ hint at increased sternal wound complications in their discussion. When looking at the Arterial Revascularization Trial, a prospective randomized trial on bilateral internal thoracic artery use, sternal wound complications were higher with bilateral internal thoracic artery grafting ${ }^{5}$; in post hoc analysis, however, the method of dissection of the bilateral internal thoracic artery graft in a skeletonized fashion was associated with decreased rate of sternal wound complications. ${ }^{6}$ Going forward, a randomized trial with true complete arterial revascularization with skeletonized bilateral internal thoracic artery and radial artery grafts may be worthy of

With another study in favor of multiarterial revascularization, why has it not been adopted more broadly throughout the country?

1. Pu A, Ding L, Shin J, Price J, Skarsgard P, Wong DR, et al. Long-term outcomes of multiple arterial coronary artery bypass grafting: a population-based study of patients in British Columbia, Canada. JAMA Cardiol. 2017;2:1187-96.

2. Schwann TA, Ramia PS, Habib JR, Engoren MC, Bonnell MR, Habib RH. Effec tiveness of radial artery based multiarterial coronary artery bypass grafting-role of body habitus. J Thorac Cardiovasc Surg. 2018;156:43-51. 
3. Habib RH, Zacharias A, Schwann TA, Riordan CJ, Durham SJ, Shah A. Effects of obesity and small body size on operative and long-term outcomes of coronary artery bypass surgery: a propensity-matched analysis. Ann Thorac Surg. 2005;79: 1976-86.

4. Executive summary of the clinical guidelines on the identification, evaluation and treatment of overweight and obesity in adults. Arch Intern Med. 1998;158: 1855-67.
5. Taggart DP, Altman DG, Gray AM, Lees B, Gerry S, Benedetto U, et al; ART Investigators. Randomized trial of bilateral versus single internal-thoracic-artery grafts. N Engl J Med. 2016;375:2540-9.

6. Benedetto U, Altman DG, Gerry S, Gray A, Lees B, Pawlaczyk R, et al; Arterial Revascularization Trial investigators. Pedicled and skeletonized single and bilateral internal thoracic artery grafts and the incidence of sternal wound complications: insights from the arterial revascularization trial. J Thorac Cardiovasc Surg. 2016;152:270-6. 